\title{
PENINGKATAN KINERJA PROFESIONALISME GURU PADA MASA PANDEMI COVID 19 MELALUI PELATIHAN PENGEMBANGAN MICROSOFT TEAMS DI SMP NEGERI 42 SURABAYA
}

\author{
Nanik Irawati ${ }^{1}$ \\ ${ }^{1)}$ SMP Negeri 42 Surabaya \\ e-mail: nanikwati@gmail.com
}

\begin{abstract}
Abstrak
Tindakan kepala sekolah dapat membuat perbedaan di lingkungan sekolah baik dari perspektif sarana dan prasarana guru dan staf. Kepala sekolah memiliki berbagai cara untuk memberikan tindakan perubahan mutu pendidikan di setiap sekolah. Penelitian ini bertujuan untuk mengetahui: (1) penerapan manajemen kepala sekolah terhadap peningkatan kinerja profesionalisme guru pada masa pandemi covid-19 melalui pelatihan pengembangan Microsoft Teams di SMP Negeri 42 Surabaya. (2) Hasil dan evaluasi guru-guru tentang pelatihan pengembangan Microsoft Teams di SMP Negeri 42 Surabaya terhadap proses pembelajaran pada masa covid-19. Pendekatan yang digunakan dalam penelitian ini melalui pendekatan pendekatan pedagodis dan edukatif. Subyek penelitian adalah seluruh guru-guru di SMP Negeri 42 Surabaya tahun pelajaran 2020/2021 sebanyak 33 guru. Data primer yaitu melalui prosedur dan teknik pengambilan data berupa observasi dan dokumentasi. Hasil penelitian ini menunjukkan Salah satu program yang terlaksanakan selama pandemi Covid-19 ialah program melakukan proses belajar mengajar secara daring melalui beberapa aplikasi yaitu Microsoft Teams. Program ini didukung oleh dinas Pendidikan kota Surabaya, pihak sekolah dan guru dalam proses pembelajaran untuk memberikan kemudahan kepada peserta didik selama pembelajaran daring di masa pandemic Covid-19. Pembelajaran menggunakan Microsoft Teams dirasa sangat efektif bagi guru-guru dan peserta didik karena mereka bisa memanfaatkan channel-channel tim dalam aplikasi Teams berupa daftar hadir, materi, penugasan, ulangan, dan menggunakan vicon (video conference).
\end{abstract}

Kata kunci: Pelatihan, Pembelajaran, Microsoft Team

\begin{abstract}
The actions of the principal can make a difference in the school environment from the perspective of teachers and staff facilities and infrastructure. Principals have various ways to provide action to change the quality of education in each school. This study aims to determine: (1) the application of principal management to improving the performance of teacher professionalism during the COVID-19 pandemic through Microsoft Teams development training at SMP Negeri 42 Surabaya. (2) The results and evaluations of teachers on Microsoft Teams development training at SMP Negeri 42 Surabaya learning process during the covid-19 period. The approach used in this study is a pedagogical and educative approach. The subjects of the study were all 33 teachers at SMP Negeri 42 Surabaya in the 2020/2021 academic year. Primary data is through procedures and data collection techniques in the form of observation and documentation. The results of this study show that one of the programs implemented during the Covid-19 pandemic is the program for conducting online teaching and learning processes through several applications, namely Microsoft Teams. This program is supported by the Surabaya city education office, schools and teachers in the learning process to provide convenience to students during online learning during the Covid-19 pandemic. Learning using Microsoft Teams is considered very effective for teachers and students because they can take advantage of team channels in the Teams application in the form of attendance lists, materials, assignments, tests, and using vicon (video conference).
\end{abstract}

Keywords: Training, Learning, Microsoft Teams, 


\section{PENDAHULUAN}

Upaya pendidikan pada hakikatnya adalah misi Tuhan Yang Maha Esa. Sehingga, manusia harus menjelaskan kepadanya semua upaya pendidikannya. Segala upaya pendidikan hendaknya menggunakan nilai dan nilai Tuhan sebagai dasar penilaian pendidikan, bukan hanya menurut nilai-nilai yang diciptakan manusia sebagai hasil renungan atas pengalaman manusia. Untuk menentukan nilai mana yang baik atau buruk bagi pendidikan (Sadulloh, 2012:88). Seperti yang tertuang dalam Undang-Undang Republik Indonesia No. 2 Tahun 1989 Bab 1, Pasal 1, Pendidikan adalah upaya sadar untuk mempersiapkan siswa melalui pengajaran dan/atau kegiatan pendidikan yang diawasi untuk peran masa depan. Pendidikan adalah proses mempengaruhi peserta didik untuk melengkapi dirinya semaksimal mungkin di lingkungannya. Misinya adalah mengarahkan proses ini agar tujuan dan perubahan pendidikan dapat tercapai sesuai keinginan (Hamalik, 2014:2).

Kepala sekolah adalah pembimbing sebagai pengelola lingkungan sekolah, dan guru berperan untuk meningkatkan kinerjanya. Tindakan kepala sekolah dapat membuat perbedaan di lingkungan sekolah baik dari perspektif sarana dan prasarana guru dan staf. Kepala sekolah memiliki berbagai cara untuk memberikan tindakan perubahan mutu pendidikan di setiap sekolah. Tindakan kepala sekolah sebagai manajer membantu meningkatkan kinerja guru dalam mewujudkan perubahan kemampuannya. Kepala sekolah, karena hal ini sudah berlangsung hampir 10 bulan, kepala sekolah bertindak berbeda untuk memastikan kemampuan kinerja guru dalam proses pembelajaran online dan guru dalam melaksanakan kegiatan pembelajaran online. Dengan mengetahui program yang dimiliki masing-masing guru, kepala sekolah menegaskan kompetensi guru dalam pelaksanaan kegiatan pembelajaran. Kepala sekolah mengevaluasi kinerja guru dengan memperhatikan kemahirannya dalam penggunaan media pembelajaran. Hal ini karena pendidikan selalu berhubungan dengan upaya pembinaan manusia, maka keberhasilan pendidikan sangat bergantung pada unsur manusianya. Unsur manusia yang paling menentukan berhasilnya pendidikan adalah pelaksana pendidikan yaitu guru.

Menerapkan model pembelajaran merupakan salah satu elemen kunci dari proses pembelajaran. Dengan diterapkannya model pembelajaran yang tepat maka proses pembelajaran dan hasil belajar akan sesuai dengan yang diharapkan. Model pembelajaran adalah seperangkat rencana atau pola yang dapat digunakan untuk merancang bahan pembelajaran dan memandu kegiatan pembelajaran di kelas atau di tempat lain di mana kegiatan pembelajaran dilakukan (Martono, 2015:71). Proses belajar dapat dilakukan kapan saja, di mana saja, dan guru dapat melanjutkan kegiatan belajarnya di dalam kelas, di luar kelas, atau di rumah. Pemanfaatan teknologi informasi dapat membantu dalam proses pembelajaran, dan guru dapat menggunakan teknologi informasi untuk pembelajaran online kursus dan pembelajaran yang dilakukan secara tatap muka. Selama ini guru hanya berpegang pada metode pembelajaran tradisional: pembelajaran tatap muka di kelas. Saat ini dunia dihebohkan dengan mewabahnya virus bernama Corona atau sering disebut Covid-19 (coronavirus disease 19). Virus ini menyebar dengan cepat ke seluruh dunia, termasuk Indonesia, dalam beberapa bulan setelah mulai menyebar di Wuhan, China. Mewabahnya Covid-19 berdampak pada berbagai sektor, mulai dari ekonomi, masyarakat, hingga pendidikan.

Di bawah pengaruh munculnya virus ini di bidang pendidikan, pada tanggal 24 Maret 2020 Menteri Pendidikan dan Kebudayaan Republik Indonesia mengeluarkan Surat Edaran Nomor 4 tahun 2020 tentang pelaksanaan kebijakan pendidikan dalam masa darurat penyebaran COVID-19. Pemerintah merekomendasikan untuk menghentikan kegiatan belajar di sekolah dan melakukan pembelajaran online untuk memutus mata rantai penyebaran virus. Sampai saat ini, tidak ada obat untuk virus COVID-19 yang ditemukan, dan desas-desus tersebar luas bahwa penyebaran virus sangat tinggi. Pemerintah telah memutuskan untuk memulai bisnis online dalam rangka mencegah penyebaran virus corona dalam menanggapi situasi ini. Pembelajaran online ini dinilai sangat efektif dalam mencegah penyebaran virus COVID-19. Proses pembelajaran online ini memiliki banyak dampak positif dan negatif. Guru didalam mengimplementasikan pembelajaran online tidak hanya mempersiapkan pembelajaran, tetapi juga memberikan materi sekreatif mungkin.

Teknologi menjadi jembatan penghubung utama dalam proses belajar mengajar pada masa pandemi ini, sebab pembelajaran harus dilakukan secara daring dan bekerja dilakukan dari rumah dalam rangka pencegahan penyebaran covid-19, sesuai dengan SURAT Edaran Mendikbud 
Nomor: 36962/MPK.A/HK/2020.5 Hal ini menjadi tantangan tersendiri bagi para guru maupun siswa untuk bisa beradaptasi dalam melaksanakan pembelajaran secara daring agar kegiatan pembelajaran yang dilakukan berjalan senyaman mungkin, efektif dan juga efisien. Selain itu juga menghasilkan output yang dapat memenuhi tuntutan masyarakat modern saat ini. Teknologi telah menjelma menjadi bagian integral dalam setiap masyarakat, yang pada dasarnya mempermudah kehidupan manusia (Miarso, 2004:466). Teknologi yang digunakan secara luas menyebabkan segala macam akses kehidupan yang dahulu terasa jauh menjadi dekat, hal ini dikarenakan semakin mudahnya manusia dalam mengakses informasi dari berbagai belahan dunia dalam satu wadah yakni internet melalui peranti elektronik berupa ponsel pintar maupun laptop dan sejenisnya.

Meningkatnya kebutuhan akan informasi dari internet tentunya sejalan dengan meningkatnya penggunaan alat komunikasi. Sehingga alat komunikasi dikembangkan sedemikian rupa agar permasalahan manusia yang membutuhkan penyelesaian cepat dapat teratasi. Perkembangan alat komunikasi dibuat seminimalis mungkin sehingga meningkatkan nilai praktis dan mudah dalam penggunaannya. Bahkan penggunanya bukan hanya orang dewasa, tetapi juga anak muda hingga remaja, dari masyarakat perkotaan hingga masyarakat yang berada di pelosok desa. Gawai atau peranti elektronik bukan hanya digunakan sebagai alat komunikasi tetapi juga dapat mengakses pencarian browser untuk menuju ke internet dan berbagai aplikasi untuk memudahkan kehidupan dengan fasilitas 3G hingga yang terbaru 4G/LTE. Kemudahan tersebut didukung dengan berbagai fitur yang ada pada gawai berupa aplikasi-aplikasi yang menawarkan nilai multiguna untuk berkomunikasi via chatting dan videocall maupun mengakses informasi juga dapat dimanfaatkan oleh kaum muda, terutama para pelajar untuk mencari beragam referensi guna memperkaya pengetahuan dan menunjang dalam belajar pada era digital ini. Meskipun kemudahan tersebut menyajikan beragam sisi positif, namun tetap memiliki dampak negatif juga, semisal kecanduan menggunakan media sosial dan aplikasi game. Penggunaan gawai dan internet yang bijaksana tentunya dapat memberikan manfaat.

Kepala sekolah menilai kinerja guru dalam melakukan program kegiatan pembelajaran secara online selama ini, kepala sekolah bekerjasama dengan satuan dinas pendidikan untuk memberikan kemudahan kepada guru dalam pelaksanaan daring untuk meningkatkan profesionalisme guru-guru di SMPN 42 Surabaya dengan adanya pelatihan pengembangan dan pemanfaatan teknologi Microsft Teams sebagai media pembelajaran daring/online. Microsoft teams merupakan sebuah alat kolaborasi yang dapat digunakan untuk percakapan, mengobrol terus menerus, panggilan telepon audio/video, meetings, file content \& folders, dan aplikasi-aplikasi bersama dalam satu waktu. Pengguna dapat menggunakan berbagai perangkat dengan keamanan dalam satu kelas. Teams sebuah aplikasi yang membantu para penggunanya mengumpulkan tim secara bersama-sama dan berkolaborasi menggunakan chat (percakapan), sebagai pengganti email, channel berisikan file dan folder (Ilag, 2018:1-2). Dan masih banyak lagi fungsi-fungsi lain pada fitur teams.

Pemberlakuan belajar dari rumah secara daring pada masa pandemi, menyebabkan banyak sekolah di Indonesia memanfaatkan berbagai aplikasi penunjang e-learning. Salah satu sekolah yang memanfaatkan e-learning berbasis aplikasi microsoft teams adalah SMPN 42 Surabaya, berbagai pembelajaran termasuk pembelajaran dilakukan dengan menggunakan aplikasi tersebut. Meskipun pelaksanaan pembelajaran jarak jauh menggunakan e-learning secara serentak di Indonesia pada wilayah-wilayah zona kuning dan zona merah akibat paparan COVID-19 terbilang sangat mendadak. Namun hal tersebut dapat menjadi tantangan tersendiri bagi sekolah-sekolah untuk menerapkan sistem pembelajaran yang berbeda.

Berdasarkan penjelasan dan berbagai permasalahan yag terjadi di SMP Negri 42 Surabaya serta kendala-kendala yang dihadapi oleh guru-guru dan peserta didik tersebut, peneliti akan memfokuskan pada penerapan manajemen Kepala Sekolah terhadap peningkatan kinerja profesionalisme guru-guru pada masa pandemi Covid-19 melalui pelatihan pengembangan Microsoft Teams di SMP Negeri 42 Surabaya.

\section{METODE}

Pendekatan yang digunakan dalam penelitian ini melalui pendekatan Pendekatan pedagodis dan edukatif. Pendekatan pedagodik yang digunakan untuk mengetahui kemampuan kepala sekolah dalam meningkatkan kinerja guru, sedangkan pendekatan edukatif pendekatan yang 
dilakukan guru terhadap siswa baik melalui daring maupun luring. Penelitian kualitatif sifatnya deskriptif analitik, seperti: hasil pengamatan, hasil pemotretan, cuplikan tertulis, dokumen dan catatan lapangan (Saifudin, 2001:21). Penelitian ini menggunakan pendekatan kualitatif karena memenuhi ciri-ciri penelitian kualitatif, yaitu: (1) kondisi objek penelitian alamiah, (2) penelitian sebagai instrument utama, (3) bersifat deskritif, karena data yang dikumpulkan berbentuk kata-kata bukan angka-angka, (4) lebih mementingkan proses (Moleong, 2009:63). Penelitian kualitatif prinsipnya untuk memahami obyek yang diteliti secara mendalam. Tujuan penelitian kualitatif pada umumnya mencakup informasi tentang fenomena utama yang dieksplorasi dalam penelitian, partisipan penelitian dan lokasi penelitian.

Selanjutnya, penelitian ini menggunakan pendekatan deskriptif kualitatif fenomenologik. Suatu penelitian yang bertujuan untuk menggambarkan, mengungkapkan dan menganalisis suatu fenomena sebagai data yang berkenaan dengan konsep, pendapat, pendirian, sikap, penilaian dan pemberian makna terhadap situasi atau pengalaman-pengalaman dalam kehidupan. Dimana pengalaman subjek penelitian bersatu secara utuh dengan subjek pendukung objek penelitian secara alami. Dalam hal ini untuk menggambarkan, mengungkapkan dan menganalisis fenomena yang berkenaan dengan konsep, pendapat, pendirian, sikap, penilaian dan memberi makna atas peran dan pengalaman kepala Sekolah SMPN 42 Surabaya membantu dan membimbing guru-guru melalui supervisi akademik dalam penerapan manajemen Kepala Sekolah terhadap peningkatan kinerja profesionalisme guru pada masa pandemi Covid-19 melalui pelatihan pengembangan Microsoft Teams di SMP Negeri 42 Surabaya tahun akademik 2020/2021.

Obyek dalam suatu penelitian merujuk pada masalah atau tema yang sedang diteliti. Sedangkan subyek penelitian merupakan individu, benda atau organisme yang dijadikan sumber informasi yang dibutuhkan dalam pengumpulan data penelitian, yang dalam penelitian kualitatif disebut informan (Idrus, 2009:59). Obyek penelitian ini adalah pelaksanaan supervisi akademik kepala sekolah dalam meningkatkan kompetensi profesional guru-guru. Subyek penelitian adalah seluruh guru-guru di SMP Negeri 42 Surabaya tahun pelajaran 2020/2021 sebanyak 33 guru.

Data yang dikumpulkan bisa lewat instrumen maupun non instrumen yang nantinya akan menghasilkan informasi, baik informasi berupa keterangan langsung dalam arti hasil kegiatannya sendiri atau pengalamannya responden maupun informasi yang didapat merupakan keterangan langsung yang bukan kegiatan sendiri atau bukan pengalamannya sendiri dari responden yang bersangkutan. Dapat disimpulkan data merupakan suatu sumber yang dapat menghasilkan informasi baik dilakukan instrument secara langsung maupun tidak secara langsung. Secara langsung instrument mengumpulkan data scara invidu berdasarkan bukan dari hasil pengalamannya responden yang bersangkuran, sedangkan secara tidak langsung, instrument melakukan berdasarkan pengalaman secara langsung dengan hasil yang diperoleh secara langsung dari responden yang berkaitan. Salah satu pertimbangan dalam memilih masalah adalah ketersediaan sumber data. Data dalam penelitian kualitatif bersifat memahami terhadap fenomena yang muncul. Yang dimaksud dengan sumber data adalah subjek darimana data diperoleh.

Terdapat dua jenis data yang digunakan dalam penelitian ini yaitu data primer dan data sekunder. Data primer merupakan data yang diperoleh langsung dari sumbernya yaitu melalui prosedur dan teknik pengambilan data berupa observasi dan dokumentasi. Data sekunder merupakan data yang diperoleh dari sumber yang tidak langsung yang biasanya berupa data dokumen dan arsip-arsip resmi. Yang termasuk data sekunder adalah: sejarah berdirinya, visi dan misi, keadaan sarana dan prasana, guru/staf.

Teknik pengumpulan data yang digunakan dalam penelitian ini adalah: Observasi dan dokumentasi. Observasi bisa diartikan dengan pengamatan dan pencatatan dengan sistematik fenomena-fenomena yang diselidiki (Hadi, 1992, hal. 136). Fenomena-fenomena yang dimaksud disini adalah hal-hal yang berhubungan dengan kompetensi aspek kepribadian dan sosial guru dalam pemanfaatan teknologi dengan menggunakan Microsoft Teams terhadap proses pembelajaran daring selama masa pandemic Covid-19 di SMPN 42 Surabaya. Sedangkan dokumentasi adalah suatu penyelidikan pada penguraian dan penjelasan apa yang telah lalu ditulis melalui sumber-sumber dokumen. Teknik dokumentasi terutama untuk keperluan data tentang siswa, guru dan berbagai dokumen sekolah yang relevan dengan keperluan pengumpulan data penelitian ini. Pada langkah-langkah pengambilan data dengan dokumentasi ini adalah 
pengumpulan data-data yang berhubungan dengan keadaan guru-guru selama pelatihan Microsoft Teams.

Analisis data dalam penelitian kualitatif, dilakukan pada saat pengumpulan data berlangsung, dan setelah selesai mengumpulkan data dalam periode tertentu. Analisis data merupakan proses mengorganisasikan dan mengurutkan data kedalam pola, kategori dan satuan uraian dasar sehingga dapat ditemukan tema dan dapat dirumuskan hipotesis kerja yang seperti disarankan oleh data (Moleong, 2009, hal. 280). Dalam penelitian tindakkan kelas ini, peneliti berpijak pada teknik analisis data Miles and Hubermen ada dalam tiga tahap (Sugiono, 2015, hal. 246):

a. Data Reduction (Reduksi Data)

Data yang diperoleh dari lapangan banyak, untuk itu perlu dicatat secara rinci dan teliti. Semakin lama peneliti terjun kelapangan maka data yang akan di dapatkan semakin banyak, maka dari itu ada hal-hal yang perlu dilakukan analisis data melalui reduksi data ini. Mereduksi data berarti merangkum, memilih hal-hal yang pokok, memfokuskan pada hal-hal yang penting, serta dicari tema dalam pokok penelitian. Reduksi data ini diambil dari hasil penelitian yang meliputi hasil observasi dan dokumentasi. Peneliti memilih data yang diperlukan dalam penelitian tentang penerapan manajemen Kepala Sekolah terhadap peningkatan kinerja profesionalisme guru pada masa pandemi Covid-19 melalui pelatihan pengembangan Microsoft Teams di SMP Negeri 42 Surabaya tahun akademik 2020/2021.

b. Data Display (Penyajian data)

Data yang sudah melewati proses reduksi, maka langkah selanjutnya adalah mendisplay data. Dalam penelitian kualitatif, penyajian data bisa dilakukan dalam bentuk uraian singkat, bagan, dan hubungan antar kategori dan lain sebagainya. Dengan adanya display data, maka akan lebih mempermudahkan apa yang terjadi. Dalam penyajian data digunakan untuk menuliskan hasil penelitian yang berkaitan tentang penerapan manajemen Kepala Sekolah terhadap peningkatan kinerja profesionalisme guru pada masa pandemi Covid-19 melalui pelatihan pengembangan Microsoft Teams di SMP Negeri 42 Surabaya tahun akademik 2020/2021.

c. Conclusion Drawing (Penarikan Kesimpulan)

Kesimpulan dan verifikasi dalam penelitian kualitatif merupakan langkah terakhir dalam menganalisis data. Pada kesimpulan awal yang dikemukakan masih bersifat sementara, dan akan berubah bila tidak ditemukan bukti-bukti yang kuat yang mendukung pada tahap pengumpulan data berikutnya. Dengan demikian, analisis dilakukan ketika peneliti berada di lapangan dengan cara mendeskripsikan hasil dari penelitian tentang manajemen Kepala Sekolah terhadap peningkatan kinerja profesionalisme guru pada masa pandemi Covid-19 melalui pelatihan pengembangan Microsoft Teams di SMP Negeri 42 Surabaya tahun akademik 2020/2021 dari hasil observasi dan dokumentasi.

\section{HASIL DAN PEMBAHASAN}

Program manajemen kepala sekolah dalam meningkatkan profesionalisme guru dengan cara meningkatkan proses pembelajaran melakukan kegiatan daring dan luring di lingkungan sekolah. Kepala sekolah membuat program untuk memudahkan peserta didik bagi peserta didik yang tidak memiliki hp dan kendala dengan jaringan. Program ini berdasarkan dari pihak dinas pendidikan untuk membuat program ini kepala sekolah menyampaikan kepada semua guru untuk melaskanakan program daring dan luring dalam pelaksanaan proses pembelajaran. Selain itu program yang dilakukan kepala sekolah adanya kegiatan-kegiatan yang berkaitan dengan mutu manajemen pendidikan, kepala sekolah dan pengawas bekerjasama guna meningkatkan mutu sekolah dan kinerja guru. Program yang dilakukan kepala sekolah tidak lepas dari hubungannya dengan lingkup sekolah. Salah satu program yang terlaksanakan selama pandemi Covid-19 ialah program melakukan proses belajar mengajar secara daring melalui beberapa aplikasi yaitu Microsoft Teams. Program ini didukung oleh dinas Pendidikan kota Surabaya, pihak sekolah dan guru dalam proses pembelajaran untuk memberikan kemudahan kepada peserta didik selama pembelajaran daring di masa pandemic Covid-19.

Sebuah hal yang baru memberikan invosi kinerja yang baru, meningkatkan kinerja dalam membuat suasana hal yang baru dalam proses pembelajaran. Sesuatu yang baru dapat memberikan 
peningkatan dan perubahan yang dulunya belum memahami dan belum tahu sekarang menjadi lebih tahu hal-hal yang baru. Standar ini merupakan sebuah program manajemen kepala sekolah dalam pengolahan dan pembentukan mutu pendidikan. 8 standar ini guru harus melengkapi kekurangan yang ada, dan melengkapi perangkat pembelajaran dan laporan selama proses pembelajaran. Kemampuan manajemen kepala sekolah harus mampu menguasai 8 standar isi dalam meningkatkan kinerja guru, salah satu syarat menjadi kepala sekolah harus mampu menguasai komtensi dasar dan mampu menguasai standar isi yang berkaitan dengan manajemen kepala sekolah.

Proses manajemen yang dilakukan kepala sekolah melalui beberapa tahapan sebagai berikut: (1) Perencanaan, (2) Pelaksanaan, dan (3) Pengawasan. Pada tahap perencanaan, pemimpin memiliki keterampilan dalam pengolahan perencanaan agar mudah mengatur, dan membuath sebuah perencanaan untuk meningkatkan kinerja dan profesionalisme guru. Kepala sekolah membuat perencanaan terhadap peningkatan profesionalisme guru salah satunya mengolah perencanaan dengan baik dan benar dan dilaksanakan dengan baik dengan melakukan pelatihan pengembangan profesionalisme guru-guru di SMPN 42 Surabaya melalui pelatihan program Microsoft Teams.

Terkait hasil evaluasi dari pelaksanaan pelatihan program Microsoft Teams terhadap implementasi pembelajaran dimasa pandemi Covid-19 ini, perencanaan program pembelajaran di bagi menjadi dua bagian ada daring dan luring. Daring dipergunakan untuk siswa yang memiliki hanphone dan jaringan internet, sedangkan luring dipergunakan untuk siswa yang tidak memiliki kelengkapan teknologi untuk melaksanakan proses pembelajaran. Adanya program ini dapat memberikan kemudahan kepada guru dalam melakukan perencanaan pembelajaran. Guru dapat melakukan perencanaan pembelajaran baik secara online maupun offline.

Dari hasil penelitian bahwa program yang dilaksanakan kepala sekolah khususnya manajemen kepala sekolah kaitannya dengan pelaksanaan pembelajaran covid 19 ini kepala sekolah membuat program pembelajaran baik secara daring dan luring. Kepala sekolah membuat program pembelajaran terhadap kaitannya dengan covid 19. Pembelajaran daring dilakukan secara online oleh semua guru dan pembelajaran luring dilaksanakan diluar dari pelaksanaan online dikerjakan secara berkumpul dengan membagi kelompok. Kepala sekolah memberikan program ini kepada siswa karena masih banyak siswa tidak memiliki hp sebagai media pembelajaran. Program pembelajaran ini berjalan dengan baik dan guru meningkatkan profesionalisme nya dalam memberikan dan membimbing siswa dalam pelaskanaan proses pembelajaran.

Kegiatan program daring dan luring ini mendukung dan membantu siswa yang tidak memiliki hp untuk melaksanakan program pembelajaran. Sedangkan untuk kegiatan daring tetap dilaksanakan oleh guru bagi siswa yang memiliki hp. Selain itu adanya laporan harian guna untuk memberikan sebagai bukti kepada pihak sekolah di adakan kegiatan proses pembelajaran. Berdasarkan paparan hasil temuan penelitian ini sebagaimana diungkapkan di atas, terkait dengan perencanaan dan program kerja dalam meningkatkan kinerja serta keprofesionalan guru dapat disimpulkan bahwa perencanaan pembinaan kinerja guru merupakan tindakan awal demi tercapainya visi dan misi SMPN 42 Surabaya ini. Oleh karena itu rencana yang dirancang oleh kepala sekolah terkait dengan pembinaan profesionalisme guru yaitu melalui kegiatan diklat, workshop atau seminar tentang pendidikan, melibatkan para guru dalam organisasi pembinaan profesi guru. Pembinaan terhadap guru merupakan salah satu cara yang efektif dan efisien yang dilakukan kepala sekolah untuk mengatur dan mengelola aktivitas bawahannya. Melalui proses pembinaan ini diharapkan bisa menumbuhkan kesadaran karakter kinerja guru untuk terus berupaya mengembangkan potensinya.

Sejak Covid-19 merebak di seluruh dunia khususnya di Indonesia dan tentunya di wilayah Surabaya pada awal April 2020 tepat pada semester genap tahun pelajaran 2019/2020, sekolahsekolah telah melaksanakan pembelajaran jarak jauh secara daring. Walau bagaimanapun, penerapan daring selama pembelajaran jarak jauh adalah satu-satunya solusi yang dapat dilakukan agar kegiatan belajar mengajar bisa terus terlaksana. Pada semester genap tahun pelajaran 2019/2020 sejak awal diterapkannya pembelajaran jarak jauh, belum ada kesepakatan bagi guruguru di SMPN 42 Surabaya untuk menggunakan daring jenis tertentu. Pembelajaran diserahkan sepenuhnya kepada masing-masing guru pengampu mata pelajaran dan kebanyakan guru hanya menggunakan aplikasi WhatsApp selama pembelajaran daring. beragam materi pelajaran serta 
contoh soal dan juga penugasan di kirim dalam bentuk file melalui aplikasi tersebut, kemudian muncul sebuah masalah yang dialami siswa/i dan juga guru, yaitu penuhnya memori ponsel. Dari situlah akhirnya pihak sekolah memikirkan sebuah cara agar masalah tersebut dapat teratasi.

Pada semester berikutnya yakni semester ganjil, tahun pelajaran 2020/2021 pihak SMPN 42 Surabaya didukung oleh dinas Pendidikan kota Surabaya untuk menerapkan pembelajaran daring berbasis aplikasi Microsoft Teams yang akan digunakan untuk semua mata pelajaran. Di dalam aplikasi tersebut terdapat ruang penyimpanan bebas memori yang cukup besar yakni 1 TB dan sudah disediakan dalam OneDrive sehingga tidak perlu menggunakan memori ponsel. Aplikasi yang wajib di download oleh para siswa/i hanya aplikasi microsoft teams, agar tidak terlalu banyak memerlukan ruang memori hp. Tetapi untuk para guru, selain aplikasi Microsoft Teams juga wajib mendownload office 365 sebagai penunjang pembelajaran dan untuk keperluan dalam membuat forms, sway, dll.

Adapun langkah-langkah yang dilakukan oleh pihak sekolah untuk mempersiapkan Microsoft Teams sebagai media pembelajaran adalah sebagai berikut: (a) Pihak sekolah merancang sistem jaringan mencakup internet yang menghubungkan sekolah dengan pusat data dan aplikasi, serta jaringan internet yang ada di internal sekolah sebagai sarana pembelajaran.; dan (b) merancang dan membuat database terkait data, informasi sekolah, akunakun guru dan juga siswa. Microsoft Teams diperkenalkan di SMPN 42 Surabaya sejak semester genap tahun pelajaran 2020/2021, tepatnya bulan Desember 2020. Tetapi sebelum diterapkan pada pembelajaran dipertengahan semester genap, para tenaga pendidik dan kependidikan diberikan pelatihan pada bulan Januari 2021 sampai Maret 2021 terkait penggunaan aplikasi microsoft teams untuk pembelajaran. Pelaksanaan pelatihan dilakukan selama 1 Minggu sekali selama 8 kali pertemuan.

Menurut penuturan dari sebagian guru-guru di SMPN 42 Surabaya melalui observasi pelaksanaan pelatihan Microsoft Teams, pembelajaran menggunakan aplikasi tersebut secara online yang telah dilangsungkan berjalan dengan lancar, namun ada beberapa peserta didik tidak dapat mengikuti pembelajaran karena ada masalah dengan kuota, jaringan, dan tidak bisa masuk ke akun teams, sehingga setelah pembelajaran online selesai mereka akan sering bertanya terkait materi pelajaran melalui WhatsApp Group. Dari hasil diskusi yang dilakukan peneliti bersama guru-guru mengenai keunggulan belajar menggunakan aplikasi Microsoft Teams adalah sebagai berikut: "Kalau keunggulannya sebenernya lebih memudahkan untuk mengajar, kita bisa memberikan tugas di channel teams, anak-anak juga angsung mengumpulkan disana dan kita bisa langsung memberikan nilai." serta "Keunggulannya bisa jarak jauh, materi dapat di simpan di elektronik masing-masing tanpa harus menulis dan lebih aman, tidak mudah terhapus riwayat chatnya jadi sewaktu-waktu mereka mau belajar tinggal buka aplikasinya." Dari hasil observasi dan diskusi tersebut, dapat disimpulkan bahwa yang menjadi kelebihan dari penggunaan aplikasi Microsoft Teams untuk pembelajaran adalah tersedianya tim-tim untuk setiap mata pelajaran dan setiap kelas yang masing-masing tim didalamnya telah terdapat channel khusus untuk pembelajaran sehingga file dan chat tidak tercampur aduk dalam satu wadah. Selain itu para siswa/i dapat terus membuka materi dan belajar dari file yang telah dikirimkan oleh guru melalui aplikasi tersebut tanpa takut riwayat chatnya terhapus.

Adapun dalam pengamatan peneliti program manajemen kepala sekolah dalam meningkatkan profesionalisme guru yakni pelatihan kepada guru-guru di SMPN 42 Surabaya terkait program Microsoft Teams sebagai platform pembelajaran daring dimasa pandemi Covid-19. Pembelajaran secara daring merupakan program selain diberikan langsung dari pemerintah ada juga program yang dilakukan disekolah yakni kurikulum dan pembelajaran merupaka sebuah program pembelajaran yang tidak bisa lepas dari profesionalisme guru. Kurikulum yang digunakan di dalam sekolah ialah kurikulum 2013 yang disederhanakan berkaitan dengan Covid-19, guru membuat kurikulum yang disederhanakan selama Covid-19 berkaitan dengan kegiatan-kegiatan di dalam grup, dalam kegiatan pembelajaran guru membuat sebuah laporan kegiatan harian dalam proses pembelajaran sebagai bukti melaksanakan proses pembelajaran. Kegiatan laporan harian terdiri dari tanggal/hari, materi, dan kegiatan pembelajaran. Guru membuat laporan kegiatan harian untuk sebagai bukti fisik dalam melaksanakan tugas-tugas dan tanggung jawabnya sebagai guru.

Penerapan pembelajaran jarak jauh di masa pandemi tentunya memiliki pengaruh yang signifikan terhadap jalannya proses pembelajaran. Baik pihak sekolah, pendidik, maupun peserta didik harus bisa beradaptasi dengan sistem pembelajaran yang baru untuk sementara waktu. Pihak 
sekolah tentunya juga telah berusaha semaksimal mungkin dalam merancang pembelajaran daring sesuai dengan kondisi wilayah agar bisa terus dilaksanakan. Kegiatan pembelajaran adalah inti penyelenggaraan pendidikan yang ditandai oleh adanya kegiatan pengelolaan kelas, penggunaan media dan sumber belajar, dan penggunaan metode dan strategi pembelajaran. Semua tugas tersebut merupakan tugas dan tanggung jawab guru yang secara optimal dalam pelaksanaannya menuntut kemampuan guru.

Pembelajaran merupakan proses tatap muka yang dilakukan antara guru dan peserta didik, namun adanya kendala dengan covid 19 siswa yang memiliki fasilitas hp android guru dan peserta didik melakukan pembelajaran jarak jauh menggunakan grup WhatssApp sehingga pembelajaran tetap berlangsung, namun jika peserta didik tidak memiliki hp sehingga guru mengumpulkan peserta didik dan melakukan tatap muka secara langsung dengan mengikuti protokol Covid-19.

Sejak diperkenalkan pelaksanan kegiatan belajar mengajar menggunakan Microsoft Teams di SMPN 42 Surabaya, berbagai permasalahan muncul yang dihadapi oleh guru-guru khususnya karena platform tersebut masih dianggap baru oleh Sebagian besar guru-guru di SMPN 42 Surabaya. Sehingga kepala sekolah sebagai pimpinan sekolah memiliki peran penting untuk mencari solusi terbaik terhadap pengembangan profesionalisme guru-guru di SMPN 42 Surabaya yaitu dengan adanya penerapan manajemen Kepala Sekolah terhadap peningkatan kinerja profesionalisme guru pada masa pandemi Covid-19 melalui pelatihan pengembangan Microsoft Teams di SMP Negeri 42 Surabaya tahun akademik 2020/2021.

Langkah-langkah yang dilakukan oleh pihak sekolah untuk mempersiapkan Microsoft Teams sebagai media pembelajaran adalah sebagai berikut: (a) Pihak sekolah merancang sistem jaringan mencakup internet yang menghubungkan sekolah dengan pusat data dan aplikasi, serta jaringan internet yang ada di internal sekolah sebagai sarana pembelajaran.; dan (b) merancang dan membuat database terkait data, informasi sekolah, akunakun guru dan juga siswa. Microsoft Teams diperkenalkan di SMPN 42 Surabaya sejak semester genap tahun pelajaran 2020/2021, tepatnya bulan Desember 2020. Tetapi sebelum diterapkan pada pembelajaran dipertengahan semester genap, para tenaga pendidik dan kependidikan diberikan pelatihan pada bulan Januari 2021 sampai Maret 2021 terkait penggunaan aplikasi microsoft teams untuk pembelajaran. Pelaksanaan pelatihan dilakukan selama 1 Minggu sekali selama 8 kali pertemuan.

Menurut Winardi dalam bukunya Manajemen Perilaku Organisasi dijelaskan bahwa "Pengorganisasian berarti mengubah rencana-rencana menjadi tindakan-tindakan dengan bantuan kepemimpinan dan motivasi. Seperti halnya di katakan kepala sekolah dalam pengorganisasian rencana yang diterapkan ialah pembuatan jadwal kepada guru dalam pelaksanaan pembelajaran. Proses pembagian Jadwal kegitan belajar mengajar dilakukan dengan tahapan melaui rapat pembagian tugas yang dilaksanakan di awal tahun ajaran. Kemudian dilaksanakan pembinaan pembuatan perangkat pembelajaran. Dalam pembagian tugas mengajar disesuaikan dengan struktur dan muatan kurikukum dan diimplementasikan ke dalam proses pembelajaran daring melalui Microsoft Teams.

Selama covid 19 ini pengawas tetap datang ke sekolah guna untuk melihat keaktifan guru dalam pelaskanaan proses pembelajaran, selain itu saya selaku kepala sekolah bekerjasama dengan pengawas untuk memperhatikan dan membimbing kinerja guru selama ini. Pengawas berkunjung di sekolah selain untuk melihat keaktifan dan kegiatan guru kami selaku guru dan pengawas bekerja sama guna untuk mengembangkan mutu manajemen sekolah. Dalam kaitannya pengamatan peneliti, pembinaan profesionalisme guru memiliki keterkaitan dan berhubungan langsung antara kepala sekolah dan pengawas, karena kedua aspek ini tidak bisa dilepaskan. Kepala sekolah dan pengawas bekerjsama dalam mengembangkan dan meningkatkan agar guruguru bisa memiliki kinerja yang baik dalam melaksanakan tugas-tugas mereka sehingga mampu mengembangk kompetensi yang dimiliki pada diri masing-masing guru.

Profesionalisme guru dilihat dari kemampuan, keterampilan dan kompetensi yang dimiliki oleh setiap guru. Berkaitan dengan kinerja guru pengawas melakukan dan memberikan penilaian 8 standar isi yang harus dilengkapi oleh guru dan pengawas 8 standar isi yakni sebagai berikut: sarana dan prasarana, standar isi, standar proses, standar penilaian, standar kelulusan, standar pengelolaan, standar tenaga pendidik dan kependidikan, dan standar pembiayaan. 8 standar isi merupakan salah satu manajemen kepala sekolah dalam meningkatkan kinerja guru. Dalam 8 
standar ini guru perlu melengkapi kekurangan yang berkaitan dengan standar isi, standar proses dan standar penilaian.

Dalam pandangan Teori Gibson bahwa kinerja guru dipengaruhi oleh dua kelompok variabel yaitu variabel individu, variabel organisasi dan variable psikologi. Dalam kaitan dengan penelitian ini variabel individu meliputi: kemampuan dan keterampilan mental fisik (dalam hal ini kemampuan dan keterampilan dalam memahami kurikulum). Kepala sekolah melakukan supervise kepada guru untuk memberikan penilaian dalam keterampilan memahami kuruikulum yang di dalamnya ialah perangkat pembelajaran seperti silabus, RPP dan penilaian tengah semester, dan penilaian akhir semester.

Selain pengetahuan guru dilihat oleh kepala sekolah, kepala sekolah memberikan penilaian kepada guru berdasarkan dari kerjasama antara orang tua siswa, dan sesama guru. Pemerintah masih menerapkan sistem Pembelajaran Jarak Jauh (PJJ) pada semester pertama tahun ajaran 2020/2021. Hal ini disebabkan masih tingginya grafik kenaikan jumlah korban Covid-19. Pembelajaran jarak jauh ini memakai sistem Daring dan Luring. Terutama untuk daerah-daerah yang masih berzona merah. Setidaknya ada 3 kendala yang saya temukan dalam pembelajaran sistem Daring dan Luring antara lain: Pertama, Penguasaan IT teruma penggunaan HP Android serta jaringan internet yang lemot. Sistem pembelajaran Daring dan Luring dapat berjalan efektif jika jaringan internetnya bagus. Sebaliknya, ketika jaringan internetnya jelek/buruk, maka secara otomatis proses Kegiatan Belajar Mengajar (KBM) online pasti terhambat. Belum lagi ada peserta didik yang membuat alasan yang mengada-ada. Artinya, banyak juga peserta didik yang mengatasmanakan jaringan jelek lalu mengurung niatnya mengikuti kegiatan pembelajaran online.

Pada semester genap tahun pelajaran 2019/2020 sejak awal diterapkannya pembelajaran jarak jauh, belum ada kesepakatan bagi guru-guru di SMPN 42 Surabaya untuk menggunakan daring jenis tertentu. Pembelajaran diserahkan sepenuhnya kepada masing-masing guru pengampu mata pelajaran dan kebanyakan guru hanya menggunakan aplikasi WhatsApp selama pembelajaran daring. beragam materi pelajaran serta contoh soal dan juga penugasan di kirim dalam bentuk file melalui aplikasi tersebut, kemudian muncul sebuah masalah yang dialami siswa/i dan juga guru, yaitu penuhnya memori ponsel. Dari situlah akhirnya pihak sekolah memikirkan sebuah cara agar masalah tersebut dapat teratasi.

Pada semester berikutnya yakni semester ganjil, tahun pelajaran 2020/2021 pihak SMPN 42 Surabaya didukung oleh dinas Pendidikan kota Surabaya untuk menerapkan pembelajaran daring berbasis aplikasi Microsoft Teams yang akan digunakan untuk semua mata pelajaran. Di dalam aplikasi tersebut terdapat ruang penyimpanan bebas memori yang cukup besar yakni 1 TB dan sudah disediakan dalam OneDrive sehingga tidak perlu menggunakan memori ponsel. Aplikasi yang wajib di download oleh para siswa/i hanya aplikasi microsoft teams, agar tidak terlalu banyak memerlukan ruang memori hp. Tetapi untuk para guru, selain aplikasi Microsoft Teams juga wajib mendownload office 365 sebagai penunjang pembelajaran dan untuk keperluan dalam membuat forms, sway, dll.

Dari hasil diskusi yang dilakukan peneliti bersama guru-guru mengenai keunggulan belajar menggunakan aplikasi Microsoft Teams adalah sebagai berikut: "Kalau keunggulannya sebenernya lebih memudahkan untuk mengajar, kita bisa memberikan tugas di channel teams, anak-anak juga angsung mengumpulkan disana dan kita bisa langsung memberikan nilai." serta "Keunggulannya bisa jarak jauh, materi dapat di simpan di elektronik masing-masing tanpa harus menulis dan lebih aman, tidak mudah terhapus riwayat chatnya jadi sewaktu-waktu mereka mau belajar tinggal buka aplikasinya." Dari hasil observasi dan diskusi tersebut, dapat disimpulkan bahwa yang menjadi kelebihan dari penggunaan aplikasi Microsoft Teams untuk pembelajaran adalah tersedianya timtim untuk setiap mata pelajaran dan setiap kelas yang masing-masing tim didalamnya telah terdapat channel khusus untuk pembelajaran sehingga file dan chat tidak tercampur aduk dalam satu wadah.

Penerapan pembelajaran menggunakan Microsoft Teams dirasa sangat efektif bagi guruguru dan peserta didik karena mereka bisa memanfaatkan channel-channel tim dalam aplikasi Teams berupa daftar hadir, materi, penugasan, ulangan, dan tidak menggunakan vicon (video conference), karena keterbatasan jaringan internet dipelosok-pelosok desa dan untuk vicon sendiri juga memakan banyak kuota sehingga ditiadakan dan jika tetap menggunakan vicon lalu ada banyak siswa/i yang tidak on pada saat pembelajaran dilangsungkan mereka akan tertinggal 
pelajaran, namun dengan menggunakan pesan teks yang dikirim di tim, mereka yang tidak sempat membuka tim karena terkendala jaringan bisa melihat riwayat chat tersebut untuk belajar.

\section{SIMPULAN}

Salah satu program yang terlaksanakan selama Covid-19 ialah melakukan proses belajar mengajar secara daring melalui beberapa aplikasi, salah satunya yaitu dengan menggunakan platform Microsoft Teams. Sejak diperkenalkan pelaksanan kegiatan belajar mengajar menggunakan Microsoft Teams di SMPN 42 Surabaya, berbagai permasalahan muncul yang dihadapi oleh guru-guru khususnya karena platform tersebut masih dianggap baru oleh sebagian besar guru-guru di SMPN 42 Surabaya. Sehingga kepala sekolah sebagai pimpinan sekolah memiliki peran penting untuk mencari solusi terbaik terhadap pengembangan profesionalisme guru-guru di SMPN 42 Surabaya yaitu dengan adanya penerapan manajemen Kepala Sekolah terhadap peningkatan kinerja profesionalisme guru pada masa pandemi Covid-19 melalui pelatihan pengembangan Microsoft Teams di SMP Negeri 42 Surabaya tahun akademik 2020/2021.

Penerapan pembelajaran menggunakan Microsoft Teams dirasa sangat efektif bagi guru-guru dan peserta didik karena mereka bisa memanfaatkan channel-channel tim dalam aplikasi Teams berupa daftar hadir, materi, penugasan, ulangan, dan menggunakan vicon (video conference). Disisi lain materi dan penugasan dengan menggunakan pesan teks yang dikirim di tim, mereka yang tidak sempat membuka tim karena terkendala jaringan bisa melihat riwayat chat tersebut untuk belajar.

\section{SARAN}

Saran-saran untuk untuk penelitian lebih lanjut untuk menutup kekurangan penelitian. Tidak memuat saran-saran diluar untuk penelitian lanjut.

Sehubungan dengan hasil penelitinn yang telah dikemukakan di atas dan berbagai keterbatasan yang dimiliki penulis dalam penelitian ini, serta implikasinya dalam upaya memberikan motivasi, semangat, dan perhatian yang serius terhadap kepala sekolah dan guru maka saran yang dapat dikemukakan dari hasil penelitian ini adalah sebagai berikut:

1. Kepada kepala sekolah agar mampu perannya sebagai seorang pemimpinnya, selain mampu mempengaruhi guru dan pegawai juga mampu memotivasi dengan memberikan reward dan punishment juga diupayakan untuk memberikan pelatihan-pelatihan dalam peningkatan kinerja dan profesionalisme guru-guru.

2. Guru diharapkan mengikuti pelatihan-pelatihan yang diberikan kepala sekolah agar nantinya dapat memaksimalkan dan membantu dalam mengatasi proses belajar mengajar sesuai dengan tujuan pemebalajran yang diharapkan

\section{UCAPAN TERIMA KASIH}

Terimakasih kepada Sekolah SMP 42 Surabaya yang sudah memberikan kesempatan dan dukungan untuk melakukan kegiatan ini hingga terselesaikannya artikel ini.

\section{DAFTAR PUSTAKA}

Arifin. (1995). Kapita Selekta Pendidikan (Islam dan Umum), Cet. Ke-3. Jakarta: Bumi Aksara.

Barlian, I. (2012). Manajemen Berbasis sekolah Menuju Sekolah Berprestasi. Palembang: Erlangga.

Bintara, W. S. (2020, Oktober 24). Pengertian Microsoft Teams | Fungsi, Manfaat, Fitur, Kelebihan. Retrieved Maret 2021, 2021, from https://dianisa.com/pengertian-microsoftteams/

Daryanto. (2013). Administrasi dan Manajemen Sekolah. Jakarta: Rineka Cipta.

Echols, J. M., \& Shadili, H. (1996). Kamus Inggris Indonesia, (Cet. 23). Jakarta: PT. Gramedia.

Fattah, N. (2013). Landasan Manajemen Pendidikan. Bandung: Remaja Rosdakarya.

Gaol, N. T. (2018). Peran Kepala Sekolah Dalam Meningkatkan Kinerja Guru, Manajemen Pendidikan, Pascasarjana Universitas Negeri Medan. Jurnal Manajemen Pendidikan 
Magister Manajemen Pendidikan FKIP Universitas Kristen Satya Wacana, e-ISSN 25499661 Volume: 5, No. 1.

Gunawan, H. (2012). Konsep dan Implementasi Pendidikan Karakter. Bandung: Alfabeta.

Hamalik, O. (2014). Proses Belajar Mengajar. Jakarta: PT. Bumi Aksara .

Idrus, M. (2009). Metode Penelitian Ilmu Sosial: Pendekatan Kualitatif dan Kuantitatif, Cet. ke-2. Jakarta: Erlangga.

Ilag, B. N. (2018). Introducing Microsoft Teams Understanding the New Chat-Based Workspace in Office 365. California: Apress.

Kambey, D. C. (2006). Landasan Teori Administrasi/ Manajemen . Manado: Tri Ganesha Nusantara.

Kunandar. (2007). Guru Profesional Implementasi Kurikulum Tingkat Satuan Pendidikan (KTSP) dan Persiapan Menghadapi Sertifikasi Guru, Cet. Ke-1. Jakarta: PT Raja Grafindo Persada.

Kurniawan, A. (2011). Kemampuan Manajerial Kepala Sekolah dalam Meningkatkan Kinerja Guru untuk Menciptakan Sekolah yang Bermutu (Penelitian di SDIT Sabilul Huda \& SDIT Sains al-Farabih). Holistik Vol 12 Nomor 01, Juni /1433.

Marno, \& Supriyanto, T. (2008). Manajemen dan Kepemimpinan Pendidikan Islam. Malang: Refika Aditama.

Miarso, Y. (2004). Menyemai Benih Teknologi Pendidikan . Jakarta: Kencana.

Moleong, L. J. (2009). Metode Penelitian Kualitatif . Bandung: PT Remaja Roskarya.

Musfah, J. (2017). Manajemen Pendidikan, Teori, Kebijakan, dan Praktik (cet.2). Jakarta: Kencana.

Namsa, M. Y. (2006). Kiprah Baru Profesi Guru Indonsia Wawasan Metodologi Pengajaran Agama Islam, Cet. Ke-1. Jakarta: Pustaka Mapan.

Saifudin, A. (2001). Metode Penelitian . Yogyakarta: Pustaka Pelajar.

Tilaar, H. (2002). Membenahi Pendidikan Nasional, Cet. Ke-1. Jakarta: PT. Rineka Cipta.

Trisnawati, E., \& Kurniawan. (2010). Pengantar Manajemen. Jakarta: Kencana. 